\title{
Isolation and characterisation of oil degrading bacteria from coastal waters and sediments from three locations in Sri Lanka
}

\author{
G. Yasodara Liyanage and Pathmalal M. Manage* \\ Department of Zoology, Faculty of Applied Sciences, University of Sri Jayewardenepura, Gangodawila, Nugegoda.
}

\begin{abstract}
Microbial degradation of petroleum hydrocarbons is one of the important pathways in the natural decomposition process. Four potential oil degrading bacteria were isolated from the coastal waters and sediments in Sri Lanka and identified as Bacillus cereus, Enterobacter sp., Enterobacter ulcerans and Micrococcus sp. by $16 \mathrm{~S}$ rRNA sequencing. The highest degradation percentage of crude oil was detected at 14 days of incubation by $B$. cereus $(84 \%)$. The remaining strains of Enterobacter sp. (80\%), Micrococcus sp. (74\%) and E. ulcerans (74 \%) were also detected as active degraders. The lowest half life time was recorded for Enterobacter sp. at 6 days of incubation, while the half life time of $B$. cereus and Micrococcus sp. was 7 days, and 10 days for E. ulcerans. The population densities of bacteria were proportional to their degradation rates. Different emulsification index values were detected starting from $18-65 \%$ for B. cereus, $48 \%$ for Enterobacter sp., $38 \%$ for Micrococcus sp., and $38 \%$ for E. ulcerans at 14 days of incubation. The FTIR spectrum analysis revealed that the peak area relevant to the C-H group's stretching $\left(2850-3000 \mathrm{~cm}^{-1}\right)$ decreased with incubation from 0.115 to 0.04 for $B$. cereus and from 0.115 to 0.08 for Enterobacter sp.. The infrared absorption wavelength range of $1455-1500 \mathrm{~cm}^{-1}$ relevant to deformations of $\mathrm{C}-\mathrm{H}$ bonds to $\mathrm{CH}_{2}, \mathrm{CH}_{3}$, and cyclohexanes decreased from 0.08 to 0.018 in $B$. cereus and from 0.08 to 0.04 for Enterobacter sp.. Among the bacterial isolates $B$. cereus was identified as the most efficient hydrocarbon degrader in the present study.
\end{abstract}

Keywords: Bacillus cereus, crude oil, Enterobacter sp., Enterobacter ulcerans, microbial degradation, Micrococcus sp.

\section{INTRODUCTION}

In the last few years a large number of ecosystems has been changed due to anthropogenic activities. It has been estimated that 1.3 million tonnes of petroleum enter the marine environment every year (NRC, 2003). Petroleum hydrocarbons can contaminate the sediment and aquatic environment due to oil spills, urban runoff, wastewater treatment plants, etc. (White et al., 2012). Accidental release of petroleum products have been recorded time to time and cause particular concerns in the environment. The hydrocarbons in crude oil contain polyaromatic hydrocarbons (PAHs), benzene and its substitutes. Cycloalkane rings are highly toxic to biota and accumulate through food chains in high concentration (Franco et al., 2004). Hydrocarbon components have been known as carcinogenic and neurotoxic organic pollutants (Admon et al., 2001). Recent studies have shown that hydrocarbons contaminate the feathers and fur of marine birds and mammals, respectively, resulting in the loss of hydrophobic properties leading to death of animals from hypothermia, or lethal doses following ingestion of oil during preening (Dave \& Ghaly, 2011).

The mechanical and chemical methods that are used to remove hydrocarbons from contaminated sites have limited effectiveness, and are not accessible to all parts of the world due to high operating and material costs. At present, physico-chemical processes such as shallow soil mining, barriers like boomers, skimmers and adsorbent materials, soil flushing, washing, and oxidative reduction are widely used to remove crude oil from contaminated sites (Potter \& Morrison, 2008; Nomac \& Cleveland, 2010). Thermal processes such as heat treatment, burning (Dave \& Ghaly, 2011), photo-remediation, and biopolymer shields (Esin \& Ayten, 2011) are used as well. All of these methods are labour intensive, need specific expertise, can be expensive and have limited effectiveness. Bioremediation is one of the most promising technologies for the treatment of hydrocarbon contaminated sites as it is cost-effective and will lead to complete mineralisation of the substrate. Bioremediation processes involve microorganisms such as yeast, moulds

* Corresponding author (pathmalalmanage@gmail.com) 
and bacteria. The recorded efficiency of biodegradation ranged from $6-82 \%$ for soil fungi, $0.13-50 \%$ for soil bacteria and $0.003-100 \%$ for marine bacteria (Rahaman et al., 2002). Recent studies have recorded the use of transgenic organisms for hydrocarbon remediation (Hanson et al., 1997). The advantage of using microbes for remediation is that they can be used both 'ex situ' and 'in-situ' depending on the location and can often be used to remove pollutants from soil, ground water, surface water and other polluted environments (Omotayo et al., 2012).

Hydrocarbon degraders have been isolated and characterised from oil contaminated environments, and tested for their petroleum degradation potential in many countries in the world. Microorganisms, namely, Actinobacter sp. and Enterobacter sp. (Hanson et al., 1997); Corynebacterium ulcerans, C. amycolatum, Bacillus badius and Micrococus varians (Omotayo et al., 2012); Yokenella spp., Alcaligenes spp., Roseomonas spp., Flavobacter spp., Sphingo bacterium spp. and Moraxella spp. (Chin et al., 2008) have been found to be involved in alkyl aromatic hydrocarbon degradation. Many Pseudomonas aeruginosa strains have been recorded to possess a strong ability to degrade crude oil and products of engine oil, pyrex, etc. (Omatayo et al., 2012). Further, in vitro experiments have revealed microbial degradation of petroleum hydrocarbons in a polluted tropical stream in Lagos by different bacteria species (Admon et al., 2001). Rahaman et al. (2002) have recorded several bacteria species that have primary degradation ability of spilled oil in the environment. Floodgate (1984) has tested 25 genera of hydrocarbon degrading bacteria and 25 genera of hydrocarbon degrading fungi, which were isolated from marine environments. Rahaman et al. (2002) have recorded that $62.7-83.1 \%$ of the total petroleum hydrocarbons (TPH) in surface soil have been converted to carbondioxide $\left(\mathrm{CO}_{2}\right)$ and water $\left(\mathrm{H}_{2} \mathrm{O}\right)$ by bioremediation. The results obtained from 'in situ' and 'in vitro' studies have concluded that bioremediation is more effective, less expensive and an easily accessible method for the treatment of hydrocarbon contaminated sites.

The present study focused on isolation, characterisation and elucidation of degradation kinetics of bacteria for crude oil degradation, since very limited information is available regarding biodegradation of petroleum contaminants in Sri Lanka. According to the authors' knowledge this is the first detailed record on the oil degradation potential of the bacteria Bacillus cereus, Enterobacter sp., Micrococcus sp. and E. ulcerans isolated from Sri Lanka.

\section{METHODOLOGY}

\section{Sample collection and physico-chemical analysis}

Sediment and water samples were randomly collected in May and June 2013 from the Colombo Port ( $6^{0} 56^{\prime}$ 28.74" N, $79^{\circ} 51$ ' 3.20" E), Negombo fishing boat landing site $\left(7^{0} 10^{\prime} 56.61^{\prime \prime} \mathrm{N}, 79^{\circ} 51^{\prime} 25.14^{\prime \prime} \mathrm{E}\right)$, and Galle Port ( $6^{0} 01^{\prime} 56.31^{\prime \prime} \mathrm{N}, 80^{\circ} 13^{\prime} 49.99$ ” E) at $10 \mathrm{~cm}$ depth, into sterile one litre pyrex glass bottles and sterile McCartney bottles. The collected samples were stored in an ice box and transferred to the laboratory within $8 \mathrm{hrs}$ of sampling and stored at $4{ }^{\circ} \mathrm{C}$ overnight until analysis. Temperature, $\mathrm{pH}$ and conductivity were measured at the site using a thermometer (model: Philip Haris, England), pH meter (model: pH 3110, WT Co., Weilheim, Germany), and conductivity meter (model: Cond 3110, WT Co., Weilheim, Germany), respectively. Dissolved oxygen (DO), nitrate and phosphate were measured using standard methods (APHA, 2014).

\section{Isolation of oil degrading bacteria}

Sediment solution for the enrichment study was prepared by adding $5 \mathrm{~g}$ of well mixed sediment samples collected in triplicate from each sampling site into $200 \mathrm{~mL}$ Erlenmeyer flasks and topped up to $100 \mathrm{~mL}$ using sterilised sea water. Water samples were prepared by directly adding $100 \mathrm{~mL}$ of sea water collected from each sampling site to $200 \mathrm{~mL}$ Erlenmeyer flasks. Prepared sediment and water samples were inoculated with $0.5 \mathrm{~mL}$ of crude oil (CEYPETCO, Sri Lanka) and incubated at $28{ }^{\circ} \mathrm{C}$ for $14 \mathrm{~d}$ at $100 \mathrm{rpm}$. After $14 \mathrm{~d}$ of enrichment, $1 \mathrm{~mL}$ aliquots were taken from the flask for isolation and enumeration of bacteria using the pour plate method [Lauryl-Bertani (LB) medium: tryptone, $9.1 \mathrm{~g}$; sodium chloride, $4.6 \mathrm{~g}$; yeast extract, $4.6 \mathrm{~g}$; agar, $13.1 \mathrm{~g}$; per litre]. After $3 \mathrm{~d}$ of incubation, bacterial colonies with different morphological characteristics were selected and re-suspended in liquid LB medium. Subsequently, pure bacterial cultures were sub cultured and stored in agar slants at $-20{ }^{\circ} \mathrm{C}$ in LB-glycerol media for further studies (Miyomoto-Shinohara et al., 2000).

\section{Crude oil utilisation by the bacterial isolates}

Isolated bacterial strains were grown in liquid LB medium as described, and starved overnight in phosphate buffer solution (PBS). Then following equalising the turbidities of the bacterial strains at $\mathrm{A}_{590}=0.35,0.5 \mathrm{~mL}$ of the bacterial suspension was inoculated into filtered sterilised $(0.2 \mu \mathrm{m}$ nucleopore $)$ sea water containing crude oil at a final concentration of $0.01 \mathrm{~g} / \mathrm{mL}$. The treated flasks were incubated at $28{ }^{\circ} \mathrm{C}$ while shaking at 
$100 \mathrm{rpm}$. The crude oil concentration of each sample was measured by spectrophotometric method (Omotayo et al., 2012) at 0,7 and $14 \mathrm{~d}$ intervals at $400 \mathrm{~nm}$. The control was treated in the same manner as the experiment without bacterial inoculation. Results were used to screen potential bacteria for oil degradation.

\section{Characterisation and identification of bacterial isolates}

The bacterial isolates were subjected to Gram stain and biochemical tests for tentative identification. Confirmation of the strains was done by $16 \mathrm{~S}$ rRNA gene sequence analysis.

\section{Degradation kinetics of the isolated bacteria}

All potential oil degrading bacterial isolates were tested against $0.01 \mathrm{~g} / \mathrm{mL}$ concentration of crude oil, and subsamples for degradation kinetics were collected at $2 \mathrm{~d}$ intervals for a period of $14 \mathrm{~d}$ (Samuel \& Oladipupo, 2012).

Oil degradation rate $(h)$ of the bacterial isolates was calculated according to the equation given bellow,

$$
h=\ln \left(C / C_{0}\right) / \mathrm{t}
$$

where $C_{0}$ and $C$ are the concentrations of crude oil at the beginning and at the end of the time interval $t$, respectively (Manage et al., 2000). Half life time was calculated as the time taken to degrade $50 \%$ of oil from the initial concentration. The degradation of oil was confirmed by FTIR method (Bhat et al., 2011) and the total viable counts (TVC) and emulsification index were detected at $2 \mathrm{~d}$ intervals.

\section{Emulsification index}

The isolated bacterial strains were grown in liquid LB medium as described previously and equalised at $590 \mathrm{~nm}$ $\left(\mathrm{A}_{590}=0.35\right)$. Two millilitres of the sample from each isolate was removed and centrifuged at $3000 \mathrm{rpm}$ for $15 \mathrm{~min}$ to collect the bacterial pellet. The pellet was suspended in PBS and $2 \mathrm{~mL}$ of crude oil was inoculated to the bacterial suspension to determine the emulsification index (Abbasi \& Amiri, 2008). The bacteria inoculated tubes were properly vortexed at $2000 \mathrm{rpm}$ for $2 \mathrm{~min}$ and allowed to stand for $24 \mathrm{hrs}$ at room temperature. The emulsification index was calculated at $2 \mathrm{~d}$ intervals for a period of $14 \mathrm{~d}$ (Abbasi \& Amiri, 2008) using the equation given below.

$E_{24}=($ height of emulsion/ height of supernatant $) \times 100$

\section{Estimation of crude oil concentration}

The residual amount of hydrocarbon present in the sample was analysed spectrophotometrically at $400 \mathrm{~nm}$ and quantified by using a calibration curve. For the estimation of residual crude oil by spectrophotometric analysis, $10 \mathrm{~mL}$ of $\mathrm{n}$-hexane (analytical grade) was added to a flask containing $1 \mathrm{~mL}$ of sample from the degradation experiment. The resulting content (hexane and sample) was transferred to a separating funnel for extraction of the crude oil. The extraction was carried out twice to ensure complete recovery of the oil. The extracted aliquot was evaporated to dryness in a water bath (model: Gemmy, YCW-010E, Taiwan) at $69{ }^{\circ} \mathrm{C}$ and the residue of the oil was dissolved in $10 \mathrm{~mL}$ of hexane after which the concentration was detected using a visible spectrophotometer (model: Labomed, Inc., USA) at $400 \mathrm{~nm}$. The crude oil concentration was obtained from the standard curve and the actual concentration using the dilution factor (Latha \& Kalaivani, 2012).

\section{Phylogenetic analysis}

To obtain a more specific picture of the bacterial taxa that were stimulated by hydrocarbon oil and bioremediation treatments, phylogenetic analysis of cloned 16S rRNA genes was performed. The phylogenetic relationships of the strains B. cereus, Enterobacter sp. and E. ulcerans were inferred by parsimony analysis of their $16 \mathrm{~S}$ rRNA sequences together with similar sequences assembled with the sequence editor Cluster $\mathrm{X}$ and Bio edit programme (Juliette et al., 1999). The 16S rRNA sequences of B. cereus, Enterobacter sp. and E. ulcerans were aligned to the most similar sequences in the National Center for Biotechnology Information (NCBI) using the align sequence programme. Pre-aligned 16S rRNA sequences (with their GeneBank accession numbers in parentheses), which were obtained from the NCBI were used for phylogenetic analysis of Bacillus cereus (KF152938), Enterobacter sp. (KM4055978) and E. ulcerans (KM504129).

\section{RESULTS}

\section{Physico-chemical parameters}

Some physico-chemical parameters of water and sediment from the Colombo Port, Galle Port and Negombo fishing boat landing sites are given in Table 1 . The mean water temperature ranged between $28-31{ }^{\circ} \mathrm{C}$ and the sediment temperature in the Negombo fishing boat landing site was the lowest $\left(29^{\circ} \mathrm{C}\right)$. The other two sites recorded a temperature of $30^{\circ} \mathrm{C}$ (Table 1). Alkaline $\mathrm{pH}$ conditions 
were detected in both sediment (8.1) and water (7.9) from the Colombo Port and an acidic condition (sediment $=6.0$ and water $=6.1$ ) was recorded in Galle Port. The highest dissolved oxygen concentration was detected in Galle Port and the lowest was recorded in Negombo fishing boat landing site. The nitrate and phosphate concentration of water and sediment in the Colombo Port was higher than those of the other two sites (Table 1).

Table 1: Physico-chemical parameters of water and sediment samples of Colombo, Galle and Negombo sampling sites (values are given as mean values of triplicates)

\begin{tabular}{|c|c|c|c|c|c|c|}
\hline \multirow[t]{3}{*}{ Parameters } & \multicolumn{6}{|c|}{ Sample sources } \\
\hline & \multicolumn{2}{|c|}{ Colombo Port } & \multicolumn{2}{|c|}{ Galle Port } & \multicolumn{2}{|c|}{ Negombo fishing boat landing site } \\
\hline & Water & Sediment & Water & Sediment & Water & Sediment \\
\hline Temperature $\left({ }^{\circ} \mathrm{C}\right)$ & $28 \pm 0.001$ & $30 \pm 0.001$ & $31 \pm 0.002$ & $30 \pm 0.002$ & $29 \pm 0.001$ & $29 \pm 0.000$ \\
\hline $\mathrm{pH}$ & $7.9 \pm 0.034$ & $8.1 \pm 0.032$ & $6.1 \pm 0.025$ & $6.0 \pm 0.031$ & $6.5 \pm 0.037$ & $6.7 \pm 0.041$ \\
\hline $\mathrm{DO}(\mathrm{mg} / \mathrm{L})$ & $4.8 \pm 0.050$ & $4.1 \pm 0.067$ & $5.6 \pm 0.052$ & $4.8 \pm 0.045$ & $4.2 \pm 0.046$ & $3.5 \pm 0.052$ \\
\hline $\mathrm{NO}_{3}^{-}(\mathrm{mg} / \mathrm{L})$ & $2.1 \pm 0.045$ & $2.3 \pm 0.047$ & $0.8 \pm 0.048$ & $1.1 \pm 0.039$ & $1.6 \pm 0.057$ & $1.8 \pm 0.045$ \\
\hline $\mathrm{PO}_{4}^{3-}(\mathrm{mg} / \mathrm{L})$ & $0.35 \pm 0.062$ & $0.31 \pm 0.067$ & $0.15 \pm 0.058$ & $0.09 \pm 0.064$ & $0.32 \pm 0.071$ & $0.25 \pm 0.073$ \\
\hline
\end{tabular}

\section{Characterisation and identification of bacterial isolates}

Based on 16S rRNA gene sequence analysis, morphological characteristics and biochemical tests, the oil degrading bacterial strains $15-\mathrm{N}-\mathrm{S}, 13-\mathrm{G}-\mathrm{S}, 26-\mathrm{C}-\mathrm{W}$ and 17-G-S were identified as B. cereus (KM504128), Enterobacter sp.(KM4055978), E. ulcerans (KM504129) and Micrococcus sp., respectively.

\section{Degradation kinetics}

The degradation of residual hydrocarbon in the media was detected at two day intervals for a period of 14 days.
Degradation percentage of the hydrocarbon varied with the species of bacteria. Bacillus cereus recorded the highest degradation ( $84 \%$ ) while Enterobacter sp., Micrococcus sp. and E. ulcerans showed $80 \%, 76 \%$ and $74 \%$, respectively (Figure 1).

Enterobacter sp. showed the lowest half life time of 6 days of incubation whereas B. cereus and Micrococcus sp. showed a half life time of 7 days. A half life time of 10 days was detected for E. ulcerens.

It was detected that both total viable counts (TVC) and emulsification index increased with increasing incubation time (Figure 2). The initial concentration

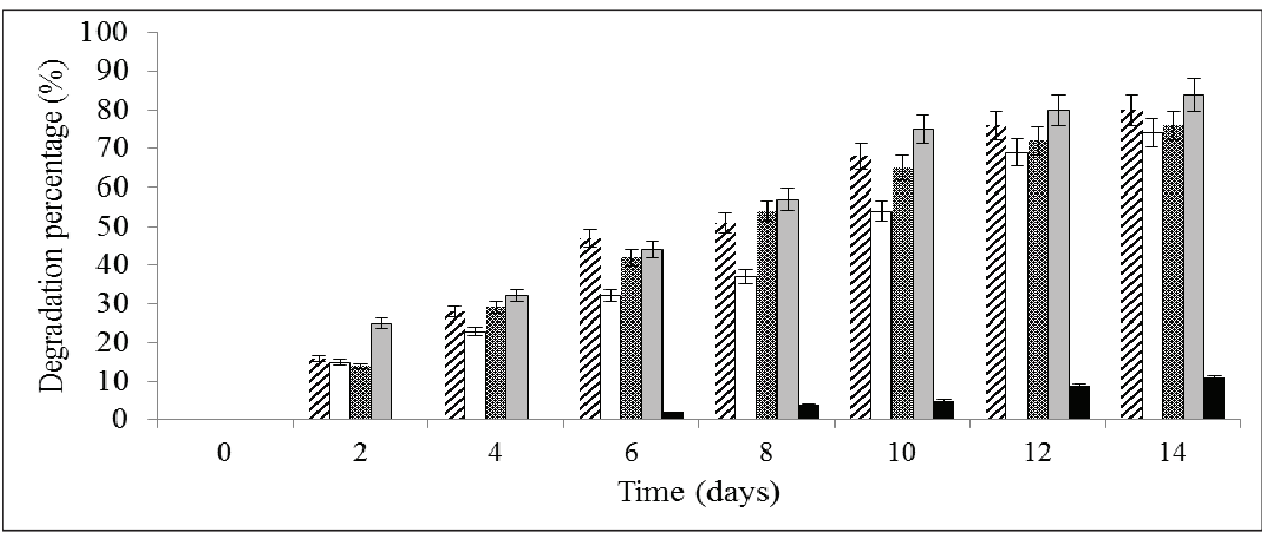

Figure 1: Bioremediation of crude oil by different bacterial isolates; control - black bars, Enterobacter sp. hatched bars, E. ulcerans - white bars, Micrococcus sp. - dotted bars, B. cereus - shaded bars 


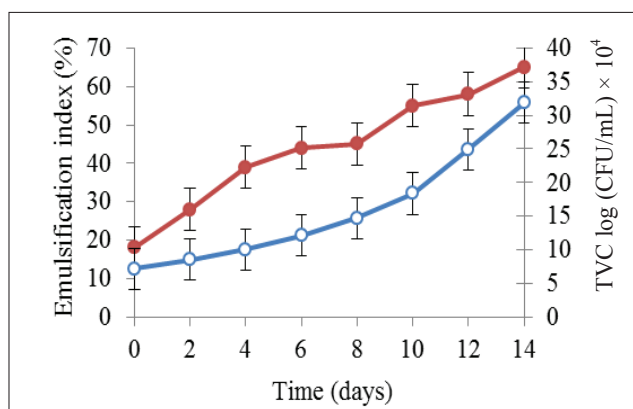

(a)

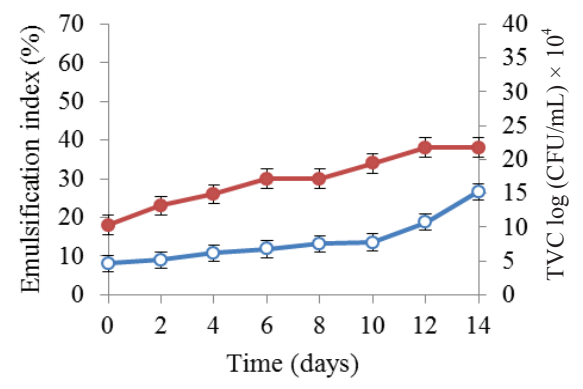

(c)

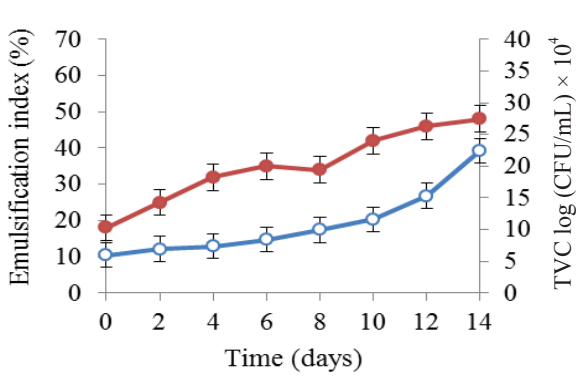

(b)

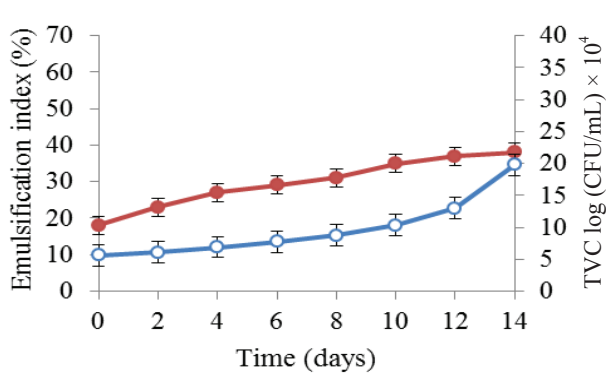

(d)

Figure 2: Changes in bacterial cell densities (given as CFU/mL) with emulsification index. (a) B. cereus; (b) Enterobacter sp.; (c) Micrococcus sp. and (d) E. ulcerans. TVC (open circle), emulsification index (closed circle)

When error bars are not shown, standard deviation is less than the width of symbol. TVC; total viable count, CFU; colony forming unit

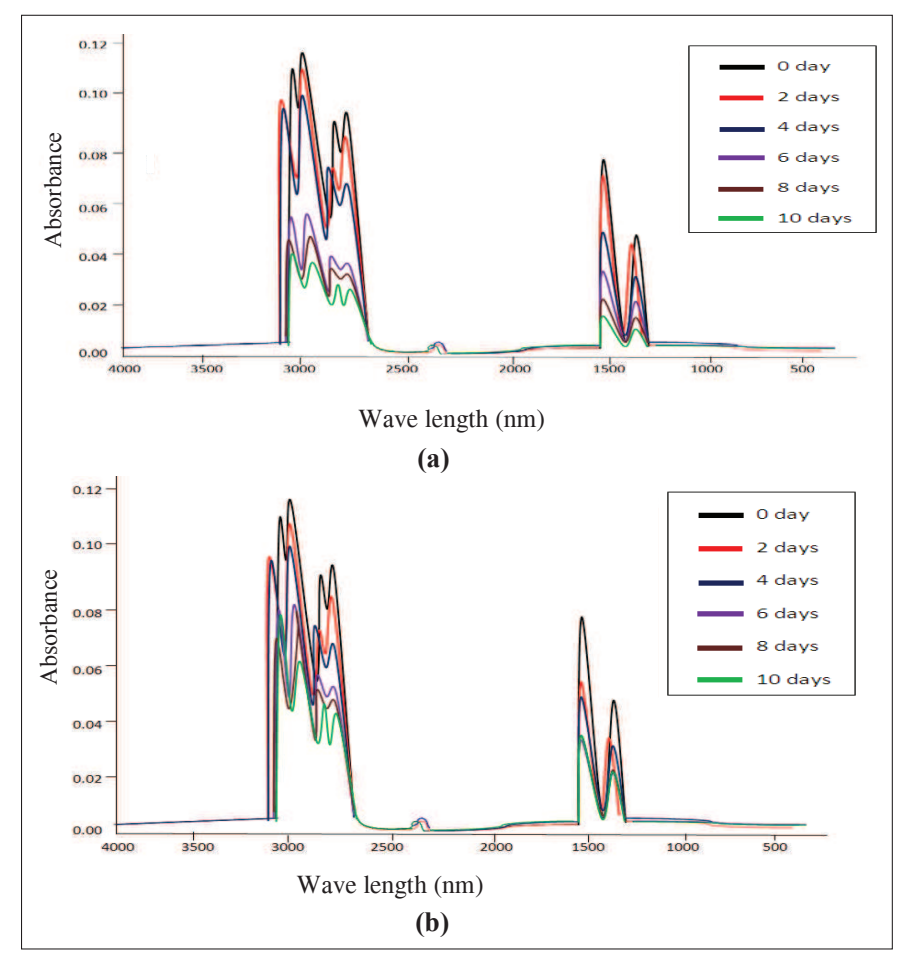

Figure 3: FTIR spectra for crude oil degradation kinetics of (a) B. cereus and (b) Enterobacter sp. 


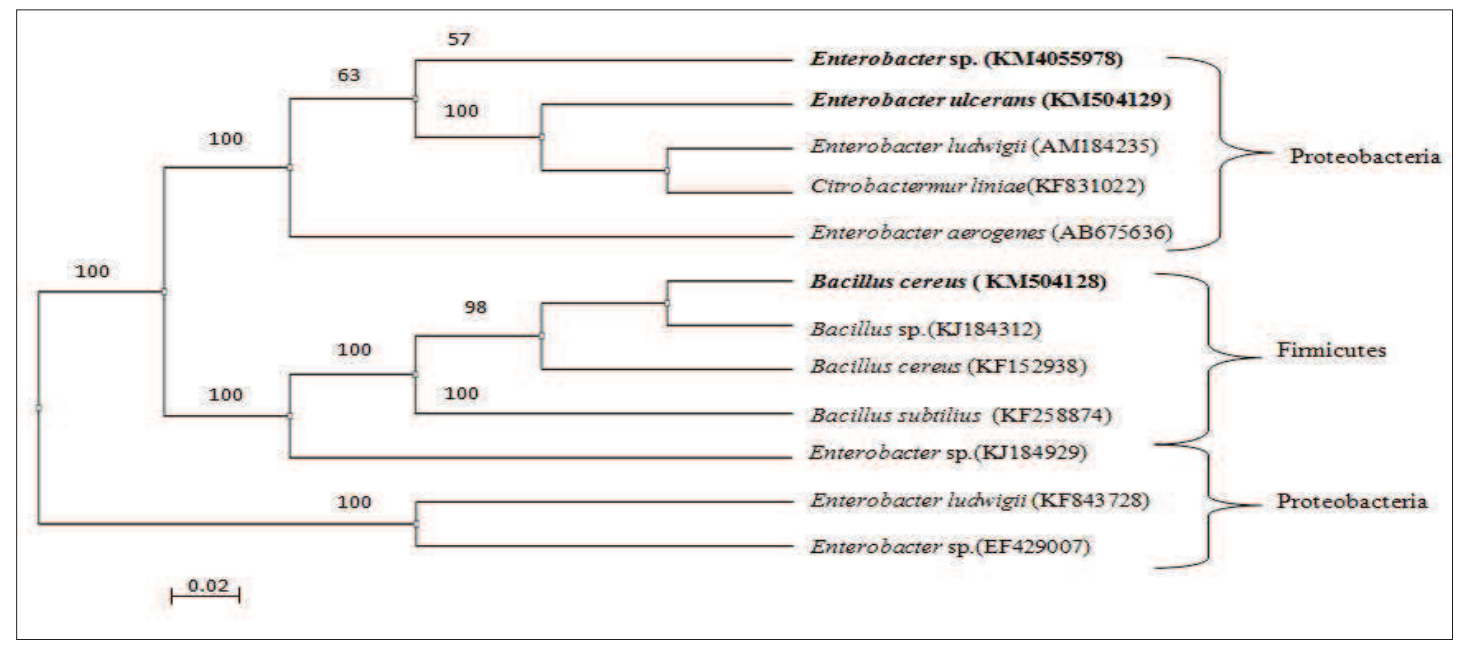

Figure 4: Phylogenetic relationship based on 16S rRNA sequences and the most closely related hydrocarbon degraders recorded, which are found from NCBI.

of bacteria was around $4.0 \times 10^{4} \mathrm{CFU} / \mathrm{mL}$ and a rapid increase in cell densities of the bacteria B. cereus (3.0 $\left.\times 10^{5} \mathrm{CFU} / \mathrm{mL}\right)$, Enterobacter $\mathrm{sp} .\left(2.0 \times 10^{5} \mathrm{CFU} / \mathrm{mL}\right)$, Micrococcus sp. $\left(2.0 \times 10^{5} \mathrm{CFU} / \mathrm{mL}\right)$ and E. ulcerans $(1.0$ $\times 10^{5} \mathrm{CFU} / \mathrm{mL}$ ) was recorded after 14 days of incubation. The emulsification index of each bacteria inoculated sample increased from $18 \%$ to $65 \%$ (B. cereus), $48 \%$ (Enterobacter sp.), $38 \%$ (Micrococcus sp.) and $38 \%$ (E. ulcerans) following 14 days of incubation.

Based on the results of degradation kinetics, B. cereus and Enterobacter sp. were selected for FTIR analysis. The FTIR spectra revealed that the peak area relevant to the C-H group stretching $\left(2850-3000 \mathrm{~cm}^{-1}\right)$ decreased with incubation time from $0.115-0.04$ for B. cereus and from $0.115-0.08$ for Enterobacter sp. (Figures $3 \mathrm{a}$ and $3 \mathrm{~b}$ ). Further, it was detected that the infrared absorption wavelength range $1455-1500 \mathrm{~cm}^{-1}$ was relevant to deformations of $\mathrm{C}-\mathrm{H}$ bonds to $\mathrm{CH}_{2}, \mathrm{CH}_{3}$ and cyclohexanes, and decreased from $0.08-0.018$ in B. cereus treatment and from $0.08-0.04$ in Enterobacter sp. treatment within 10 days of incubation.

\section{Phylogenetic analysis}

The most parsimonious tree generated by Bio-edit for B. cereus, Enterobacter sp. and E. ulcerans is shown in Figure 4. The genus Enterobacter is identified as proteobacteria and genus Bacillus is identified as in firmicutes group. The phylogenetic analysis showed that there was a close relationship between the genera Enterobacter and Bacillus.

\section{DISCUSSION}

Sri Lanka is known as one of the worst polluters of the Indian Ocean (NCEAS, 2012). Unplanned land use practices, release of wastewater to coastal and terrestrial environments and shipping activities in the Indian Ocean consequently contaminates the ocean water with hydrocarbons and inorganic chemicals etc. (MEPA, 2012).

The use of conventional methods to remove environmental contaminants have resulted in threats to aquatic life. Use of bioremediation processes to remove environmental contaminants is an eco-friendly method. Recent in vitro and in situ studies have revealed that the use of microbes for cleaning environmental pollutants is accessible in all parts of the world as a cost effective and highly efficient method.

Bioremediation is an environment friendly and cost effective method of removing or degrading pollutants like hydrocarbons in contaminated environments (Omotayo et al., 2012). Bacteria are the most active microorganisms in petroleum degradation and they work as primary degraders of spilled oil in the environment (Rahaman et al., 2002).

The presence of preferred environmental conditions for bacterial growth and reproduction can result in efficient degradation of contaminants. Leahy and Colwell (1990) have reported that most of the bacteria prefer $6-8$ $\mathrm{pH}$ and $28-31^{\circ} \mathrm{C}$ temperature for the optimal growth and 
biodegradation of petroleum. In the present study, it was detected that water and sediment $\mathrm{pH}$ were in the range of $6-8.1$ in all sampling sites and thus, the environmental conditions prevailing in the areas from where the bacteria were isolated are favourable for optimal bacterial growth and oil degradation.

Several hydrocarbon degrading bacteria have been isolated from sediment and aquatic sources and tested for their petroleum degradation potential in many countries (Mittal \& Singh, 2009). Arthrobacter sp., Burkholder sp., Mycobacterium sp., Pseudomonas sp., and Bacillus sp. etc. were recorded to be involved in hydrocarbon, petroleum degradation and their degradation efficiencies increased from $0.13 \%$ to $80 \%$ and $100 \%$ (Rahaman et al., 2002). The present study showed efficient oil degraders with varying degradation percentages. Among the 60 isolated strains, B. cereus, Micrococcus sp., E. ulcerans and Enterobacter sp. were identified as fast growing bacteria in crude oil. Several other studies have also reported the above strains as biodegraders of oil (Leahy \& Colwell, 1990; Banat et al., 2000; Latha \& Kalaivani, 2012; Omotayo et al., 2012).

Nwaogu et al. (2008) have reported that after 30 days of incubation B. subtilus degrades $65 \%$ of the crude oil whereas the present study showed more than $84 \%$ degradation by $B$. cereus after 14 days of incubation (Figure 1).

Bacillus cereus showed the highest population density when compared to the other bacterial isolates (Figure $2 \mathrm{a})$. The cell density increased from $7.0 \times 10^{4} \mathrm{CFU} / \mathrm{mL}$ to $3.0 \times 10^{5} \mathrm{CFU} / \mathrm{mL}$ when the crude oil concentration decreased from $0.01 \mathrm{~g} / \mathrm{mL}$ to $0.0016 \mathrm{~g} / \mathrm{mL}$. Similar results have been recorded by Omotayo et al. (2012) for Corynebacterium sp., Bacillus sp. and Micrococcus sp. However, Omotayo et al. (2012) have recorded that the increase of bacterial cell densities during the oil bioremediation process was ten times lower than the results of the present study. Furthermore, Atlas and Hazen (2011) have recorded that the half life time of crude oil degradation by $B$. subtilus was 8 days whereas the present study recorded a 7-day half life time for B. cereus.

Bhat et al. (2011) have noted that the bands at $2925.1 \mathrm{~cm}^{-1}$ and $1027.2 \mathrm{~cm}^{-1}$ indicate the C-H stretching in aliphatic region and $\mathrm{C}-\mathrm{O}$ stretch for primary alcohols, respectively. Elena and John (2003) have reported that the range $3000-3100 \mathrm{~cm}^{-1}$ is an indication of $\mathrm{C}-\mathrm{H}$ stretching in aromatic compounds. Thus, the results of the present study (Figure 3) suggest that B. cereus and Enterobacter sp. prefer both $\mathrm{C}-\mathrm{H}$ aliphatic and aromatic stretches to degrade long chain alkanes in crude oil. The FTIR results further confirmed cleavage $\mathrm{OH}$ stretching by bacteria. This was evident by the decreasing peak area with height.

Emulsification activity and emulsification index are used to determine the bio surfactant producing activity of bacteria (Kishore \& Ashisk, 2007). Bio surfactant activities indirectly represent the quantity of bio surfactant produced and directly involved in the process of hydrocarbon removal from the environment through increased bioavailability and subsequent biodegradation of the hydrocarbons by direct cell contacts (Leahy \& Colwell, 1990; Banat et al., 2000). The emulsification indices (Figure 2) shown in the study could be attributed to the ability of the bacterial isolates to clean up the oil effectively.

\section{Acknowledgement}

The authors wish to thank the University of Sri Jayewardenepura for providing the financial support.

\section{REFERENCES}

1. Abbasi A. \& Amiri S. (2008). Emulsified behaviour of an exopoly saccharide produced by Enterobacter cloacae. Biotechnology 7: 1574 - 1576.

2. Admon S., Green M. \& Avnimelech Y. (2001). Biodegradation kinetics of hydrocarbon in soil during land treatment of oily sludge. Bioremediation 5(3): 193 - 209. DOI: http://dx.doi.org/10.1080/20018891079285

3. American Public Health Association (APHA) (2013). Standard Methods for the Examination of Water and Wastewater. American Public Health Association, Washington DC, USA. Available at: https://www. standardmethods.org/ViewArticle.cfm? articleID $=98$, Accessed 25 November 2014.

4. Atlas R.M. \& Hazen T.C. (2011). Oil biodegradation and bioremediation; a tale of the two worst spills in US history. Environmental Science and Technology 45(16): 6709 - 6715 .

DOI: http://dx.doi.org/10.1021/es2013227

5. Banat I.M., Makkor R.S. \& Cameotra S.S. (2000). Potential commercial applications of microbial surfactants. Applied Microbiology and Biotechnology 53: 495 - 508.

DOI: http://dx.doi.org/10.1007/s002530051648

6. Bhat M.M., Shankar S., Shikha, Yunus M. \& Shukla R.N. (2011). Remediation of hydrocarbon contaminated soil through microbial degradation- FTIR based prediction. Advances in Applied Science Research 2(2): 321 - 326.

7. Chin K.J., Sharma M.L., Russel L.A. \& Lovely D.R. (2008). Quantifying expression of a dissimilatory (bi) sulfitereductase gene in petroleum-contaminated marine harbor sediments. Microbial Ecology 55: 489 - 499. DOI: http://dx.doi.org/10.1007/s00248-007-9294-2 
8. Dave D. \& Ghaly A.E. (2011). Remediation technologies for marine oil spills; a critical review and comparative analysis. Environmental Sciences 7: 423 - 440.

9. Elena D.R. \& John P. (2003). A study of the bioremediation effect on contaminated soil. Indian Academy of Science 112: 109 - 116 .

10. Esin E. \& Ayten K. (2011). Bioremediation of crude oil polluted soils. Biotechnology 3: $206-213$.

11. Floodgate G.D. (1984). The fate of petroleum in marine ecosystems. Petroleum Microbiology (ed. R.M. Atlas), pp. 355 - 379. Macmillan, New York, USA.

12. Franco I., Contin M., Bragato G. \& Nobili M. (2004). Microbiological resilience of soils contaminated with crude oil. Geoderma 121: 17 - 30.

DOI: http://dx.doi.org/10.1016/j.geoderma.2003.10.002

13. Hanson K.G., Nigam A. \& Kapadia M. (1997). Bioremediation of crude oil contamination with Acinetobacter sp. Microbiology 35: 191 - 193.

14. Juliette N.R., Robert T.A., Jocelyn L.F. \& Derek R.L. (1999). Microbial communities associated with anaerobic benzene degradation in a petroleum contaminated aquifer. Applied and Environmental Microbiology 65: 3056 - 3063.

15. Kishore D. \& Ashisk M. (2007). Crude petroleum oil biodegradation efficiency of Bacillus subtilis and Pseudomonas aeruginosa strains isolated from a petroleum contaminated soil. Bioresource Technology 98(7): $1339-1345$.

DOI: http://dx.doi.org/10.1016/j.biortech.2006.05.032

16. Latha R. \& Kalaivani R. (2012). Bacterial degradation of crude oil by gravimetric analysis. Advances in Applied Science Research 3(5): 2789 - 2795.

17. Leahy J.G. \& Colwell R.R. (1990). Microbial degradation of hydrocarbons in the environment. Microbiology and Molecular Biology Reviews 54: 305 - 315.

18. Manage P.M., Zen'ichiro K. \& Shin-ichi N. (2000). Algicidal effect of the bacterium Alcaligenes denitrification on Microcystis spp. Aquatic Microbial Ecology 22: 111 - 117. DOI: http://dx.doi.org/10.3354/ame022111

19. Marine Environment Protection Authority (MEPA) (2012). Oil Spill Events. Marine Environment Protection Authority, No. 758, $2^{\text {nd }}$ Floor, Baseline Road, Colombo 09. Available at www.mepa.gov.lk/web/index.php?option $=$ com_content
$\&$ view $=$ article $\&$ id $=56 \&$ itemid, Accessed 29 November 2013.

20. Mittal A. \& Singh P. (2009). Isolation of hydrocarbon degrading bacteria from soils contaminated with crude oil spills. Biology 49(4): $760-765$.

21. Miyomoto-Shinohara Y., Imaizumi T., Sukenobe J., Kawamura S. \& Komatsu Y. (2000) Survival rate of microbes after freeze drying and long term storage. Cryobiology 41(3): 251 - 255.

DOI: http://dx.doi.org/10.1006/cryo.2000.2282

22. National Center for Ecological Analysis and Synthesis (NCEAS) (2012). Marine debris; scale and impact of trash in ocean ecosystem, Available at www.nceas.ucsb.edu/ product, Accessed 05 January 2014.

23. National Research Council of the National Academies (NRC). (2003). Oil in the Sea; Inputs, Fates and Effects. The National Academic Press, Washington DC, USA.

24. Nomac M. \& Cleveland C. (2010). Oil Spill Control Technologies. Available at http:// www.eoearth.org/ articles/view $/ 158385 /$ ?topic $=50366$, Accessed 07 January 2014.

25. Nwaogu L.A., Onyeze G.O.C. \& Nwabueze R.N. (2008). Degradation of diesel in a polluted soil using Bacillus subtilius. Biotechnology 7(12): 1939 - 1943.

26. Omotayo A.E., Ojo O.Y. \& Amund O.O. (2012). Crude oil degradation by microorganisms in soil composts. Microbiology 7: $209-218$.

27. Potter S. \& Morrison J. (2008). World catalogue of oil spill response products. Ross Environmental Research Ltd., Ottawa, Canada.

28. Rahaman P.K., Rahaman T. \& Banat I.M. (2002). Occurrence of crude oil degrading bacteria in gasoline and diesel station soil. Microbiology 42(4): 284 - 291.

29. Samuel E.A. \& Oladipupo O.O. (2012). Box-Behnken design application to study enhanced bioremediation of soil artificially contaminated with spent engine oil using biostimulation strategy. Energy and Environment 31(3): $52-56$.

30. White H.K., Xu L., Hartmann P., Quinn J.G. \& Reddy C.M. (2012). The unresolved complex mixture in coastal environments derived from petroleum sources. Environmental Science and Technology 47: 726 - 731. DOI: http://dx.doi.org/10.1021/es3042065 